\title{
NILAI-NILAI GOTONG-ROYONG DALAM TARI MBUAH PAGE (ANALISIS SEMIOTIKA NILAI-NILAI GOTONG-ROYONG DALAM \\ TARI MBUAH PAGE PADA ACARA ADAT MERDANG-MERDEM DI DESA PERBESI KECAMATAN TIGABINANGA KABUPATEN KARO SUMATERA UTARA)
}

\author{
Evariana BR Brahmana/Christina Rochayanti/M. Edy Susilo \\ Jurusan Ilmu Komunikasi FISIP UPN "Veteran" Yogyakarta \\ Jl. Babarsari No. 2 Tambakbayan Yogyakarta 55282, Telp. (0274) 485268 \\ Hp. 081392522090 / e-mail : brabe9irlz@yahoo.com
}

\begin{abstract}
This research, entitled "Nilai-nilai Gotong-royong Dalam Tari Mbuah Page" (Analisis Semiotika Nilai-nilai Gotong-royong Dalam Tari Mbuah Page pada Acara Adat Merdang-merdem di Desa Perbesi Kecamatan Tigabinanga Kabupaten Karo Sumatera Utara). This research starts from the assumption that the Mbuah Page dance as one of the traditional arts are not just as a means of entertainment, but loaded with deep values. This dance is one of the traditional dance of the Karo people who are still found in traditional event Merdang-Merdem in Perbesi Village . This dance is used as media to convey the message of values mutual assistance. Mbuah Page dance describes how villagers conducting a series of activities in the fields, ranging from rice planting until harvest results. This research aimed to identify the symbols used in Mbuah Page dance on Merdang-merdem ceremony.

The research method used in this study is qualitative and interpretative methods of interpretation Semiotics of Roland Barthes. Analysis of the data in this study are exploratory descriptive explanations to describe and explain a phenomenon. Test the validity of data is a source of triangulation to strengthen the analysis in this research.

The results mentioned that Mbuah Page dance used the media to convey the message the values of mutual assistance. The message was built by the symbolism inherent in the dance, among others, whole body movements of dancers, musical accompaniment, traditional clothing and other devices all of which have relationships with one another. It can be concluded from this research process have meanings that explain the noble values of mutual help and Mbuah Page dance became the media to convey the message to the public about the importance of a spirit of mutual assistance in a life together.
\end{abstract}

Key words : culture, traditional dance, Batak Karo

\section{Pendahuluan}

Pulau Sumatera merupakan salah satu pulau terbesar di Indonesia dan memiliki penduduk dengan beraneka ragam suku. Suku Batak merupakan salah satu suku yang dapat ditemui di Sumatera bagian Utara yang ber-ibukota Medan. Suku Batak ini terbagi lagi menjadi beberapa sub bagian dengan adat istiadatnya masing-masing, antara lain Batak Toba, Batak Mandailing/ Angkola, Batak Simalungun, Batak Karo, dan lainlain. Suku Karo memiliki berbagai macam upacaraupacara adat, antara lain seperti Merdangmerdem, Kerja Nereh Empo, Perumah Begu, dan lain-lain. Bagi masyarakat Karo, berbagai pertunjukan seni itu memiliki makna lebih dari sekedar seni, yaitu makna spiritual (Prinst, 1996). 
Salah satu budaya Karo atau upacara adat Karo yang merupakan warisan turun temurun dan masih dipertahankan sampai sekarang yaitu Merdang-merdem. Tujuan diadakannya Merdang-merdem ini yaitu untuk menjaga ketentraman dan keseimbangan kehidupan masyarakat dan sekaligus membangun solidaritas sosial masyarakat, selain itu tujuannya adalah memohon perlindungan lahir dan bathin kepada Tuhan Yang Maha Esa serta terhindar dari kegagalan panen. Hal ini tercermin ketika semua warga desa selaku penyelenggara kegiatan terlibat secara langsung atau tidak langsung dalam peristiwa desa yang dianggap penting yang hanya diselenggarakan sekali dalam setahun.

Desa Perbesi merupakan salah satu desa di tanah Karo yang masih menyelenggarakan acara Merdang-merdem setiap tahunnya. Desa ini merupakan salah satu desa terbesar dan terpadat penduduknya di tanah Karo. Bahkan sebagian besar penduduk di desa ini sudah banyak yang merantau hampir ke seluruh penjuru Indonesia. Namun, hampir sebagian besar penduduk yang merantau tersebut pasti pulang kampung setiap tahun untuk bisa mengikuti acara Merdangmerdem dan dapat berkumpul dengan seluruh anggota keluarga.

Tari Mbuah Page merupakan salah satu tarian yang menjadi ciri khas desa Perbesi ketika Merdang-merdem. Tari Mbuah Page ini memiliki keistimewaan tersendiri bagi penduduk desa karena tarian ini hanya dapat ditemui di Desa Perbesi. Keistimewaan lain dari tarian ini, yaitu tarian ini secara umum menggambarkan kegiatan orang-orang di sawah, yaitu mulai dari menanam padi sampai dengan memanennya, dan semuanya itu terangkum dalam sebuah tarian.

Cerita di balik Tari Mbuah Page ini berkaitan dengan hubungan antara orang Karo di jaman dahulu dengan Dewi Padi, Beru Dayang Jile-jile yang diyakini sebagai pembawa padi kepada orang Karo. Kisah Beru Dayang Jilejile yang turun ke bumi untuk memberikan pengetahuan kepada orang Karo tentang cara menanam padi dan menjadikan padi sebagai makanan pokoknya agar orang Karo di kala itu tidak lagi hidup dan mencari buah-buahan untuk dimakan di tengah hutan. Akan tetapi karena kesombongannya, orang Karo justru sering sekali melakukan kesalahan dengan merusak makanannya sendiri, yang pada akhirnya justru merugikan dirinya sendiri. Namun, Beru Dayang Jile-jile tetap bersabar dan memberikan kesempatan kepada orang Karo untuk belajar dari kesalahannya dan berpesan agar orang Karo selalu menghargai pengetahuan yang diberikan oleh Beru Dayang Jile-jile serta senantiasa menghormati padi sebagai makanan pokok mereka yang membuat orang Karo dapat bertahan hidup. Selain itu, Beru Dayang Jile-jile juga berpesan untuk hidup saling tolong-menolong dan bergotongroyong diantara sesama.

Alasan pemilihan judul tersebut didasari oleh gambaran realita yang ada sekarang ini, yaitu cenderung menggesernya nilai-nilai gotong-royong didalam kehidupan masyarakat Indonesia. Hal tersebut cenderung diakibatkan oleh modernisasi yang kian pesat yang kurang lebih membuat masyarakat cenderung bersifat individualis dan egois. Dari sisi-sisi negative modernisasi tersebut, juga membawa dampak negative bagi orang Karo, antara lain: (a) kegotong-royongan, kebersamaan, tradisi lama akan goyah, sementara nilai-nilai baru belum mengkristal; (b) kebutuhan material semakin meningkat, sementara kemampuan untuk mencapainya masih terbatas.

Dapat dirasakan bagaimana modernisasi telah banyak melunturkan nilai-nilai budaya yang ada pada orang Karo, terutama nilai-nilai gotongroyong yang sangat di junjung timggi oleh orang Karo yang sangat menghormati persaudaraan diantara sangkep enggeluh. Inilah penyebab utama, identitas orang Karo menjadi kabur.

Berdasarkan uraian di atas, maka dapat diketahui bahwa kehidupan budaya orang Karo memiliki banyak makna-makna yang tersembunyi, salah satunya adalah makna gotong-royong dalam tarian Mbuah Page padaAcara Merdangmerdem di desa Perbesi. Namun, seiring modernisasi yang kian pesat dan membawa dampak negative bagi masyarakat, tak terkecuali orang Karo, makna-makna gotong-royong dalam budaya yang dimiliki dan telah turun-temurun di wariskan oleh leluhurpun kian terkikis dan semakin tidak dimengerti oleh sebagian besar orang Karo. Maka dariitu, lewat penelitian ini perlu bagipeneliti 
untuk membuka kembali pemahaman orang Karo akan adanya makna gotong-royong dalam tari Mbuah Page pada acara Merdang-merdem di desa Perbesi Kecamatan Tigabinaga Kabupaten Karo, Sumatera Utara.

Penulis mengacu pada teori Semiotika, yaitu suatu ilmu atau metode analisis untuk mengkaji tanda. Semiotika pada dasarnya hendak mempelajari bagaimana kemanusiaan (humanity) memaknai hal-hal(things). Memaknai (to signify) dalam hal ini tidak dapat dicampuradukkan dengan mengkomunikasikan (to communicate). Suatu tanda menandakan sesuatu selain dirinya sendiri. Makna (meaning) ialah hubungan antara obyek atau idea dan suatu tanda (Littlejohn dalam Sobur, 2003:15-16).

Teori Roland Barthes dikenal dengan Two Way of Signification (pemaknaan dua tahap). Ada dua tingkatan dalam pemaknaan sebuah teks, yaitu denotasi dan konotasi. Denotasi merujuk pada makna sebenarnya pada tanda, dimana maknanya sesuai dengan apa yang tampak dan dapat dengan mudah dikenali atau didefinisikan. Sedangkan konotasi merujuk pada makna yang terdapat dibalik denotasi, tetapi tergantung padanya. Konotasi membaca tanda oleh audien dengan pemaknaan di luar makna yang sebenarnya dan makna yang ada di dalam aturan (Kurniawan, 2001:22-23).

\section{Metode Penelitian}

Jenis penelitian yang digunakan adalah metode penelitian kualitatif dengan menggunakan analisis semiotika yang dikemukakan oleh Roland Barthes. Penelitian initidak memaparkan, menjelaskan hipotesa atau mengujinya melainkan hanya mengembangkan, menjelaskan, memaparkan konsep, fakta, data yang diperoleh dari penelitian tersebut dan mencoba memaparkan dan menjelaskan makna simbol-simbol gotong-royong dalam Tari Mbuah Page.

Teknik pengumpulan data yang dilakukan penulis adalah dengan menggunakan:dokumentasi dan studi pustaka.

Adapun teknik analisa data yang digunakan adalah dengan tahapan-tahapan sebagai berikut: (a) tari Mbuah Page diamati secara mendalam untuk mengenali penanda-penanda (signifier); (b) hasil pengamatan tersebut kemudian dicari makna tersurat yang disebut makna denotasi dari tarian ini; (c) pengamatan kemudian dilanjutkan secara lebih mendalam dan intens untuk menemukan makna konotatifnya; (d) menarik kesimpulan berdasarkan analisis semiotika.

Uji validitas data dengan menggunakan teknik triangulasi sumber, yaitu membandingkan dan mengecek balik derajat kepercayaan suatu informasi yang diperoleh melalui waktu dan alat yang berbeda dalam metode kualitatif (Moleong 1991 : 178). Hal tersebut dapat dicapai dengan cara; (1) membandingkan data hasil pengamatan dengan data hasil wawancara; (2) membandingkan dengan apa yang dikatakan orang lain secara pribadi; (3) membandingkan hasil wawancara dengan isi dokumen yang berkaitan.

\section{Hasil Penelitian dan Pembahasan \\ Tari Mbuah Page Mengandung Nilai-nilai Gotong-royong}

Gotong-royong dapat dipandang sebagai suatu sistem nilai yang melatarbelakangi suatu kebiasaan untuk saling tolong-menolong. Semangat gotong-royong ini didasari oleh suatu pandangan bahwa, manusia tidak hidup sendiri melainkan hidup bersama dengan orang lain atau lingkungan sosial lainnya, pada dasarnya manusia itu bergantung pada orang lain, dan karena itu manusia perlu menjaga hubungan baik dengan sesamanya dalam suasana persaudaraan.

Orang Karo pada umumnya memilki sikap hidup saling gotong-royong dalam hidup bersama dan berdampingan dengan orang lain. Hal ini juga tercermin dalam berbagai acara-acara adat orang Karo yang merupakan perwujudan dari adanya gotong-royong dan tolong-menolong dalam menyelesaikan acara adat tersebut, seperti pesta perkawinan, kematian, dan lain-lain. Dalam hal pertanianpun orang Karo tidak dapat bekerja sendiri, orang Karo biasanya bekerja secara berkelompok dalam pertanian, atau yang sering disebut dengan aron. Aron inilah yang secara bersama-sama bekerja di ladang, mulai dari menanam sampai memanen hasilnya.

Tari Mbuah Page juga merupakan gambaran gotong-royong dalam pertanian yakni dari 
mulai menanam padi sampai memanen hasilnya. Sangat terlihat dengan jelas dalam serangkaian gerak tubuh penari dalam tarian ini yang menggambarkan bagaimana padi mulai di tanam, disiangi, dan selanjutnya dipanen. Inilah yang menjadi ciri khas orang Karo, yakni adanya keinginan untuk saling gotong-royong dalam hidup bersama untuk mencapai hasil yang diharapkan.

Di dalam pembahasan ini, bahwa Tari Mbuah Page merupakan media komunikasi yang mampu menyampaikan pesan dengan menggunakan tanda. Tanda (sign) yang menggambarkan suatu realita yang ditunjukkan untuk mengkaji nilai-nilai gotong-royong. Pada Tari Mbuah Page ini terdapat beberapa gerakan yang memiliki hubungan satu dengan yang lainnya sehingga terbentuk sebuah nilai gotong-royong. berikut ini adalah serangkaian gerakan dalam Tari Mbuah Page yang dianalisis dengan menggunakan analisis Semiotika Roland Barthes.

\section{Gambar 1. Gerakan Mencangkul}

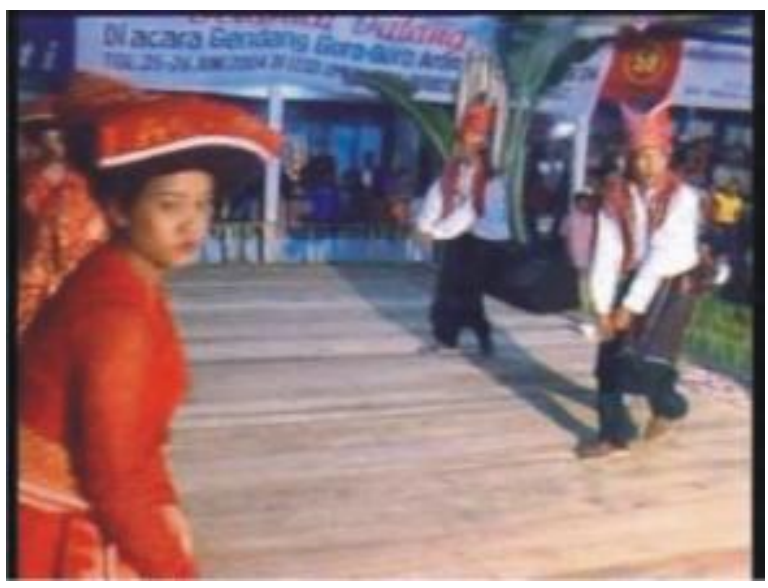

Pada tataran denotasi gambar 1, dapat dilihat bahwa penari seolah-olah membawa cangkul. Kedua tangan dikepal dan diayunkan ke kanan atas dan ke bawah secara bergantian dan secara perlahan. Posisi tubuh dari penari ini sedikit agak dibungkukkan. Kedua kaki diayun bergantian sambil berpindah tempat dengan pasangan yang didepannya secara perlahan dan kembali lagi ke posisinya semula. Para penari wanita mengenakan tudung sebagai penutup kepala, baju kebaya merah, uis nipes yang diikatkan di pinggang dan uis julu yang dipakai sebagai sarung. Sedangkan pada penari pria memakai bulang-bulang sebagai penutup kepala, beka buluh yang dilipat hingga membentuk segitiga sama sisi dan diletakkan dikedua bahu (cengkok-cengkok) dan uis gatip jongkit yang dipakai sebagai sarung yang hanya dipakai sebatas betis pria dewasa.

Gerakan pada tarian ini menggambarkan suatu kegiatan mencangkul di ladang, sebagai proses awal untuk menggemburkan tanah sebelum akhirnya ditanami. Kegiatan menggemburkan tanah dengan cangkul merupakan kegiatan yang masih tradisional, mengingat sudah semakin berkembangnya alat-alat yang modern untuk menggemburkan tanah seperti bajak ataupun traktor. Namun, bagi sebagian besar masyarakat desa, menggemburkan tanah dengan menggunakan cangkul merupakan kegiatan yang masih sering mereka lakukan dan masih sering ditemui di daerah-daerah pedesaan.

Gerakan kaki kanan penari yang sedikit

Gambar 2 Gerakan Nuan Page (menanam Padi)

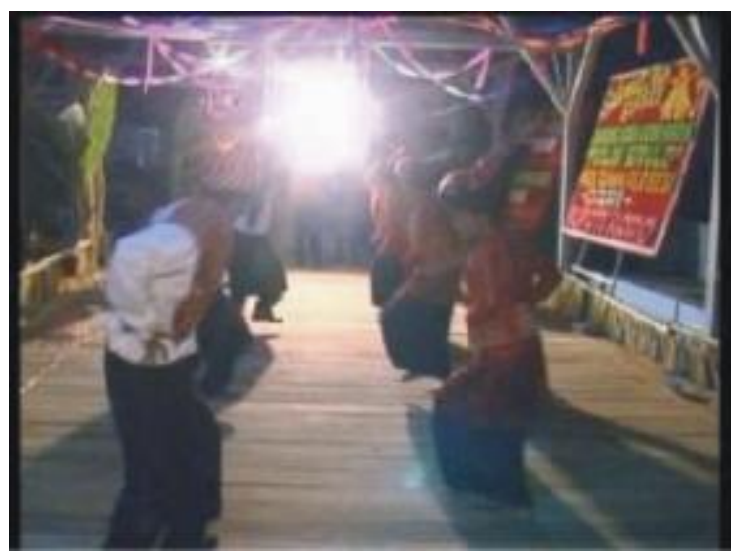

ditekankan ke lantai pada gambar 2 yang menunjuk pada kegiatan membuat lubang di tanah. Gerakan ini sarat dengan nilai-nilai gotong-royong mengingat kegiatan menanam padi di perladangan tidak dapat dilakukan hanya seorang diri tetapi harus melibatkan banyak orang, apalagi area perladangan yang biasanya digunakan untuk menanam padi bukanlah area yang kecil. Orang Karo mengenal istilah menukal dalam perladangan, yakni membuat lubang ditanah tempat bibit ditanamkan. Kegiatan ini harus dilakukan secara berpasangan dan beriringan dan biasanya dilakukan oleh pemuda 
dan pemudi. Pemuda dengan meng-gunakan kayu simpur membuat lubang di tanah dan selanjutnya di belakang pemuda ini diikuti pemudi yang menabur bibit padi ke dalam tanah yang telah diberi lubang tersebut. Tudung yang dikenakan oleh penari wanita dan bulang-bulang yang dikenakan penari pria mengartikan bahwa kebiasaan orang Karo yang pasti menggunakan penutup kepala untuk melindungi kepala dari teriknya panas matahari selama melakukan kegiatan di perladangan.

\section{Gambar 3 Gerakan Mengarit}

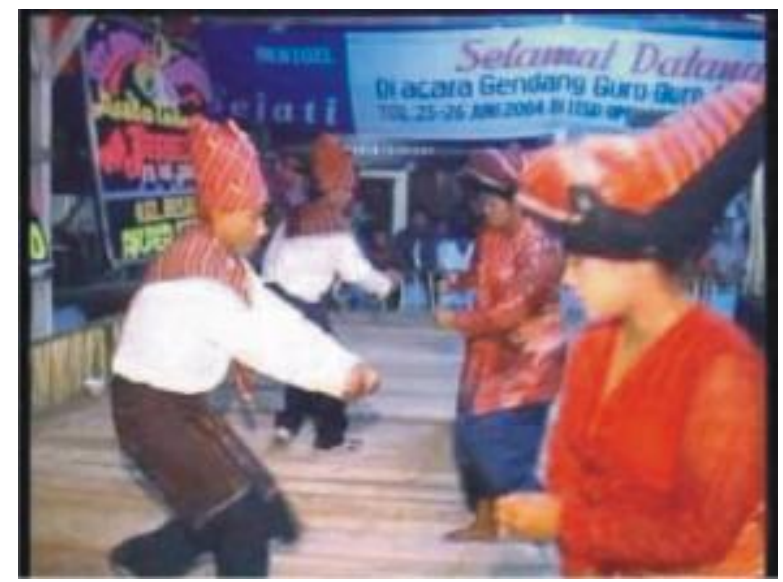

Gerakan tangan kiri yang menggenggam padi dan tangan kanan memegang arit yang dilakukan oleh seluruh penari secara serentak pada gambar 3, menggambarkan adanya kegiatan gotong-royong yang dilakukan aron untuk memanen padi yang jumlahnya tidak sedikit.

Gambar 4 Gerakan Narsari (Memisahkan Padi dari Jerami)

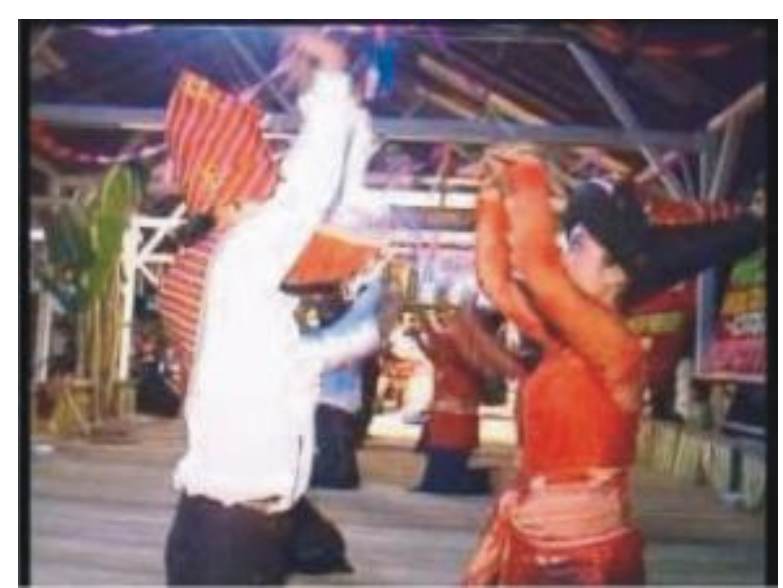

Iringan musik Mbuah Page pada gerakan ini membuat seluruh penarinya seolah-olah sedang melakukan kegiatan di perladangan yang akhirnya membuat gerakan mereka semakin bersemangat.

Posisi berlutut seluruh penari dengan jarak yang tidak terlalu jauh, sambil mengayunkan tangan ke atas dan ke bawah secara bergantian pada gambar ini menunjuk pada kegiatan narsari atau memisahkan padi dari sisa-sisa jerami. Mengingat hasil panen yang tidak sedikit, para aron harus saling bergotong-royong agar kegiatan tersebut

Gambar 5 Gerakan Ercibal (Ucapan Syukur Kepada Dewa)

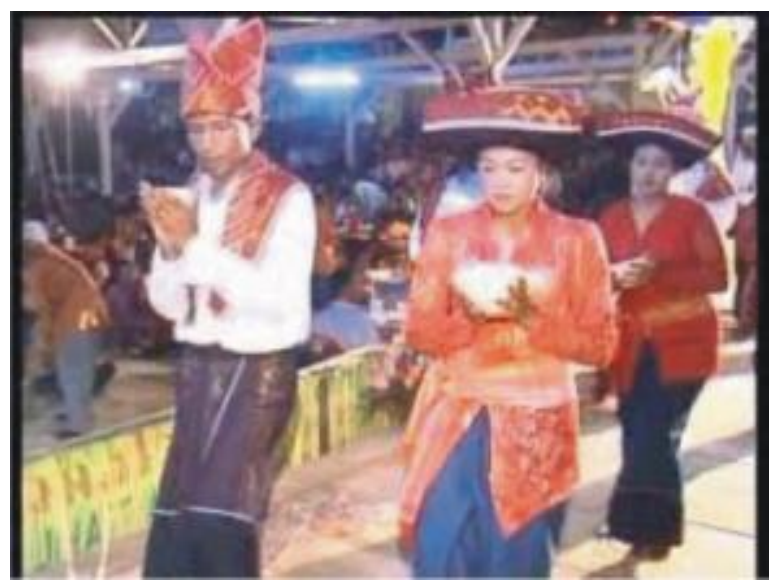

dapat selesai dengan cepat.

Pada gambar 5, penulis melihat nilai gotong-royong terletak pada mangkuk putih berisi beras yang dipegang oleh seluruh penari. Mangkuk putih berisi beras tersebut merupakan sesajen yang diberikan kepada Beru Dayang Jile-jile agar

Gambar 6 Perayaan Gendang Muda-mudi

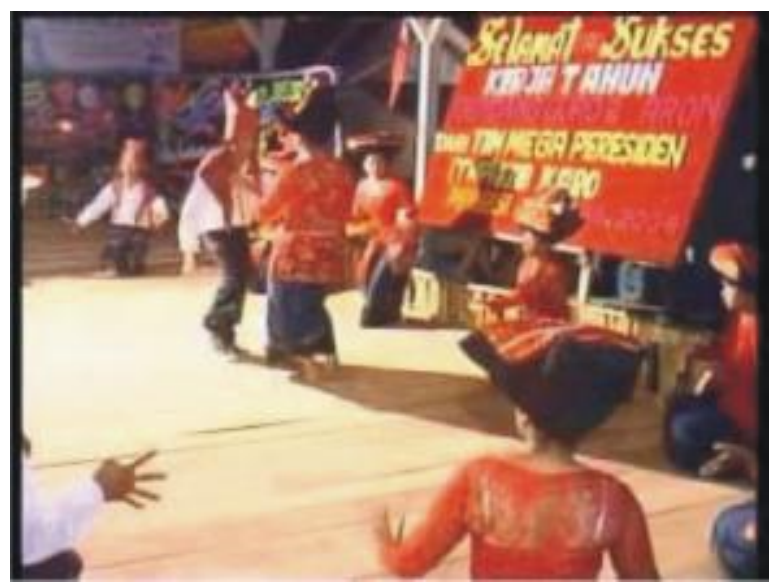


tetap memberkati perladangan sehingga panen dapat berkelimpahan. Mengingat sesajen yang diperlukan cukup komplit, maka seluruh penduduk desa harus secara bersama-sama dan bergotongroyong mempersiapkan sesajen yang akan diberikan kepada Beru Dayang Jile-jile yang diyakini oleh orang Karo sebagai Dewi Padi. Iringan musik Gendang Guru pada gerakan ini mengingatkan penari akan penghormatan kepada Beraspati Taneh dan Beru Dayang Jile-jile sebagai penguasa padi agar selalu ingat untuk saling gotong-royong.

Pada gambar 6 , penulis melihat nilai gotong-royong pada lingkaran yang dibentuk oleh seluruh penari. Lingkaran ini merupakan suatu wujud ercakap-cakap (musyawarah) yang dilakukan penduduk desa untuk membuat sebuah perayaan sebagai ucapan syukur atas panen yang melimpah, yang mana pada akhirnya memerlukan gotong-royong seluruh penduduk desa untuk dapat menyukseskan kegiatan tersebut mengingat banyaknya hal-hal yang harus dipersiapkan. Perpaduan musik Patam-patam dan musik Mejuah-juah yang mengiringi gerakan ini menandakan bahwa serangkaian kegiatan perladangan telah usai dan adanya kesukacitaan berkat panen yang melimpah.

Gotong-royong pada umumnya merupakan kesadaran akan kehidupan yang saling tolongmenolong diantara sesama masyarakat dan adanya keikhlasan untuk ikut terlibat dalam berbagai kegiatan pada masyarakat. Sebagai mahkluk sosial, orang Karo tidak dapat memenuhi kebutuhan hidupnya tanpa pertolongan orang lain. Bantuan yang diberikan untuk menolong orang lain diberikan tanpa mengharapkan suatu imbalan atau balasan, tetapi semata-mata sebagai kesadaran sebagai konsekuensi dari pergaulan hidup bersama dalam masyarakat. Sehingga gotong-royong sudah menjadi sebuah kebudayaan yang kian dilestarikan oleh orang Karo dalam berbagai aspek kehidupannya.

Istilah kebudayaan sering diartikan sama dengan kesenian, terutama seni suara dan seni tari. Akan tetapi apabila istilah kebudayaan diartikan menurut ilmu-ilmu sosial, maka kesenian merupakan salah satu bagian saja dari kebudayaan. Melville J. Herskovits dan Bronislaw Malinowski mengemukakan bahwa Cultural Determinism berarti segala sesuatu yang terdapat di dalam masyarakat ditentukan adanya kebudayaan yang dimiliki oleh masyarakat itu (Soekanto, 1990: 171172).

Walaupun setiap masyarakat mempunyai kebudayaan yang saling berbeda satu dengan lainnya, namun setiap kebudayaan mempunyai sifat hakikat yang berlaku umum bagi semua kebudayaan dimanapun juga. Sifat hakiki kebudayaan tersebut antara lain: (1) kebudayaan terwujud dan tersalurkan lewat perilaku manusia; (2) kebudayaan telah ada terlebih dahulu mendahului lahirnya suatu generasi tertentu, dan tidak akan mati dengan habisnya usia generasi yang bersangkutan; (3) kebudayaan diperlukan oleh manusia dan diwujudkan tingkah-lakunya; (4) kebudayaan mencakup aturan-aturan yang berisikan kewajiban-kewajiban, tindakan-tindakan yang diterima dan ditolak, tindakan-tindakan yang dilarang dan tindakan-tindakan yang diijinkan (Soekanto, 1990:182-183).

Kebudayaan gotong-royong pada orang Karo yang diwujudkan dalam upacara penghormatan kepada tanah sebelum memulai perladangan kini semakin ditinggalkan oleh orang Karo. Berdasarkan hasil wawancara yang dilakukan peneliti dengan budayawan Karo, Bapak Mada Sembiring, hal tersebut terjadi karena disebabkan oleh beberapa faktor, antara lain; (1) orang Karo yang semakin berfikir modern dan cenderung rasional semakin tidak meyakini akan hal-hal yang mengandung nilai-nilai mistis seperti yang terkandung dalam serangkaian upacara-upacara tersebut; (2) orang Karo yang telah beragama semakin yakin bahwa kelimpahan dari hasil panen tidaklah tergantung dari serangkaian ritual-ritual yang dipanjatkan kepada Beraspati Taneh dan Beru Dayang Jile-jile, melainkan berkat kerja keras dan usaha orang Karo sendiri. Bahkan kegiatan menanam padi tidak lagi hanya dilakukan sekali dalam setahun, tetapi dapat juga dilakukan tiga kali dalam setahun, tergantung bagaimana kesiapan pemilik ladang dan keadaan cuaca di daerah tersebut; (3) orang Karo semakin memiliki kesibukan masing-masing yang semakin kompleks sehingga tidak memiliki banyak waktu untuk mempersiapkan hal-hal yang berkaitan dengan 
ritual-ritual kepada Beraspati Taneh. Apalagi upacara ini memakan waktu yang tidak sebentar dan melibatkan banyak orang.

Karena alasan tersebut, berbagai ritualritual untuk menghormati Beraspati taneh dan Beru Dayang Jile-jile kini semakin ditinggalkan. Merdang-merdem yang sejatinya adalah serangkaian ritual yang dilakukan sebelum memulai suatu perladangan kini hanyalah suatu upacara tradisional Karo yang lebih mengarah pada acara kesukacitaan dan kumpul-kumpul dengan seluruh sanak keluarga sambil makan-makan bersama sebagai tanda bahwa panen telah berhasil dan hasilnya tidak mengecewakan.

Walaupun serangkaian upacara-upacara perladangan ini semakin hilang dari budaya orang Karo, orang Karo tetap memegang teguh gotongroyong dalam kehidupan bersama, khususnya dalam hal pertanian. Walaupun maknanya juga sudah mengalami pergeseran. Kalau dulu, orang Karo saling bergotong-royong karena adanya kesadaran akan kehidupan yang saling tolongmenolong diantara sesama masyarakat dan adanya keikhlasan untuk ikut terlibat dalam berbagai kegiatan di masyarakat. Gotong-royong dianggap sebagai kewajiban yang tidak memberatkan. Akan tetapi sekarang ini, gotong-royong yang dilakukan aron dalam pertanian bukan karena kesadaran atau karena kewajiban yang tidak memberatkan, tetapi sudah bermakna adanya pemenuhan kebutuhan hidup. Gotong-royong yang dilakukan lebih mengarah kepada adanya upah atau imbalan yang akan diterima setelah melakukan pekerjaan tersebut.

Hasil interpretasi penulis menunjukkan bahwa Tari Mbuah Page yang telah melalui proses pemaknaan dua tahap (denotasi dan konotasi) sarat dengan simbol-simbol, gerakan seluruh tubuh penari, musik pengiring, pakaian tradisional, dan perangkat-perangkat lainnya yang masih berhubungan sehingga dapat mengandung nilai-nilai gotong-royong. Selain itu, tarian ini juga membuktikan bentuk kecintaan penduduk desa Perbesi akan salah satu tarian tradisional Karo yang mulai dilupakan oleh masyarakat dan adanya suatu usaha dari masyarakat desa Perbesi untuk melestarikannya dengan menampilkannya pada acara Guro-guro Aron ketika Merdang-merdem di desa tersebut. Melalui tarian ini juga diharapkan dapat membuka ingatan orang Karo secara umum dan penduduk desa Perbesi secara khusus akan semangat gotong-royong yang telah mereka lakukan dan pentingnya menjaga semangat gotong-royong tersebut agar tetap ada di hati seluruh orang Karo dimanapun berada.

\section{Simpulan}

Berdasarkan hasil penelitian dan analisis menggunakan metode Semiotika pada Tari Mbuah Page, dapat disimpulkan bahwa Tari Mbuah Page dijadikan media untuk menyampaikan pesan kepada masyarakat. Pada Tari Mbuah Page, terdapat makna pesan yang ingin disampaikan oleh seluruh penari, yaitu nilai-nilai luhur gotong-royong seperti yang digambarkan oleh penari selama melakukan kegiatan di perladangan. Pesan tersebut dibangun oleh simbol-simbol yang terdapat pada Tari Mbuah Page, antara lain gerakan seluruh tubuh penari, musik pengiring, pakaian tradisional yang dikenakan oleh penari dan perangkatperangkat lainnya. Kesemuanya itu saling memiliki hubungan satu dengan yang lainnya sehingga muncul sebuah makna pesan arti pentingnya sebuah semangat gotong-royong dalam kehidupan bersama. Nilai-nilai gotong-royong yang senantiasa dibudayakan oleh orang Karo hingga kini serta rasa hormat yang ditunjukkan orang Karo terhadap sangkep enggeluh dalam kehidupan sehari-hari merupakan suatu nilai mulia yang patut dicontoh.

Tari Mbuah Page sebagai khasanah budaya bangsa Indonesia yang menjadi kebanggaan bangsa, merupakan salah satu sarana media yang efektif, komunikatif, dan tontonan yang memberikan tuntunan dan sekaligus tuntutan kepada masyarakat dalam memupuk dan menumbuh suburkan kecintaan terhadap kebudayaan nasional.

\section{Daftar Pustaka}

Fiske, John, 2004, Culture And Communication Studies, Jalasutra, Yogyakarta.

Ginting, Ukur, 2008, Adat Karo Sirulo, Untuk Kalangan Sendiri, Medan.

Kurniawan, 2001, Semiologi Roland Barthes, Yayasan Indonesia, Magelang.

Moleong, Lexy, 1991, Metodologi Penelitian

Kualitatif, PT. Remaja Rosdakarya, 
Bandung.

Prinst, Darwan, 1996, Adat Karo, Kongres Kebudayaan Karo, Medan.

Sinaga, dkk, 1985, Upacara Tradisional Yang

Berkaitan Dengan Peristiwa Alam dan

Kepercayaan Daerah Sumatera Utara,

Depdikbud Kebudayaan Daerah, Jakarta.
Sobur, Alex, 2002, Analisis Teks Media, PT. Remaja Rosdakarya, Bandung. 2003, Semiotika Komunikasi, PT. Remaja Rosdakarya, Bandung.

Soekanta, Soerjono, 1990, Sosiologi Suatu Pengantar, PT. Raja Grafindo Persada, Jakarta. 